[DOI: 10.24214/jecet.A.9.4.72838.]

Jaurnal of Enviranmental Science, Computer Science and Engineering \& Technology An International Peer Review E-3 Journal of Sciences and Technology

\author{
Available online at www.jecet.org
}

Section A: Environmental Science

Research Article

\title{
Potential Traditional Food of Olele Based Village Tomini Bay Area as a Gastronomic Tourist Attraction
}

\author{
Yumanraya Noho', Meilinda L. Modjo ${ }^{2}$, Poppy Arnold Kadir ${ }^{3}$ \\ ${ }^{123}$ Department of Tourism, Gorontalo State University, Gorontalo, Indonesia
}

Received: 15 October 2020; Revised: 03 November 2020; Accepted: 10 November 2020

\begin{abstract}
This research was conducted to find the potencies of Traditional Foods in Olele Village as a Gastronomy Tourist Attraction. The research used qualitative method. Primary data collection is conducted by observation and in-depth interviews to the local people. Besides that, a literature study is also conducted. Data analysis uses an interactive model, through three activities carried out simultaneously, namely reduction of data, presentation of data, and a conclusion. The results showed that Olele Village's has several unique cuisines, they are Tuna Satay, Jaw and Breast Tuna Roasted, and Tuna soup. These cuisines were originally used fresh Yellow Fin Tuna from Tomini Bay around Olele Village. The challenges of local people so that Gastronomy tourist attraction can be developed are preparing a physical building that can involve the tourists into a gastronomy activities starts from processing raw Tuna, showing the cooking process, until serving the cuisine. The challenge is preparing the local people as Human Resources so they have the ability in packaging the gastronomy tourism in Olele Village.
\end{abstract}

Keywords: Potency, Traditional Food, Gastronomic tourism

\section{INTRODUCTION}

Iculinary industry as stourism sector in Indonesia, it has contributed 41 percent of the total revenue of the tourism sector and the creative economy in 2017. In fact, this sector is able to absorb a workforce of up to 8.8 million people (ugm.ac.id, 2019). (International Culinary Tourism Association /CTA) defines culinary tourism as a tourist activity to enjoy unique food and drinks when traveling to a country. Nowadays we can see the high number of impressions on television and electronic 
mediapopular social media, such as Instagram, Facebook, and Youtube, which present culinary events from all corners of the country.

Behind this culinary richness are the many the community only emphasizes the function of food which is a source of supply for human physical needs, on the other hand, studies of gastronomy and its foodscape, to support gastro-city and gastronomic tourism are still rarely done ${ }^{[1,2]}$. The concept of gastronomic tourism itself has been very popular abroad, but in Indonesia it is still not heard.Manolis [3] defining gastronomy as anything related to the enjoyment of eating and drinkingunique and embedded in the minds of food connoisseurs. The perspective on food and beverages on the concept of gastronomic tourism is broader and holistic in a unified process starting from the search for history, selection of raw materials, preparation of cooking utensils, technology for cooking, and presentation that emphasizes nutritional content. Clave and $\mathrm{Knafou}^{[4]}$ state that the characteristics of gastronomic tourism consist of: (1) Gastronomy as an element and indicator of globalization; in particular, the affirmation of regional competition around the world; (2) Tourists provide a role in the evolution of gastronomic tourism; (3) Tourism as a revealer of regional or local gastronomic potential and as a contributor to developing or renewing national and subnational identities; (4) Gastronomic tourism as a means of introducing culinary products as cultural products; (5) The evolution of gastronomic tourism provides direction for tourism development; (6) Gastronomy as a constructive element in shaping the image of a tourist destination: (7) Gastronomy as a tourist destination; (8) Gastronomy as an element of heritage with a tourist dimension; (9)Gastronomy is also the main motive behind the actors who prepare and who motivate the availability of food and beverage ingredients, such as cultivators, farmers, fishermen, animal hunters, cooks, or whatever their title or qualification is.

The Tomini Bay area is geographically endowed with various richesfishery resources, marine and terrestrial biota diversity as well as exotic local cultural wealth. Gorontalo Province as one of the provinces bordering Tomini Bayalso have the availability of food resources from the sea and plantations that have created a heritage of local food that has a characteristic delicious taste, and relies purely on raw material sources that can be obtained from the region itself. Some traditional Gorontalo foods that are quite popular are being promoted, including Binthe Biluhuta (milu siram), Yiloni Chicken, Bilendango Fish, Woku, Nike Yilepao, and various other snacks such as tili aya, sabongi, and tutulu (local food name). In fact, most of these traditional foods we can find still use simple cooking technology passed down from generation to generation with the taste of maintaining the taste of the food.

Observing the potential of food resources along with various ways of processing food based on the culture of local communities in the Tomini Bay area, the authors are interested in conducting research on the potential for food and beverages in coastal village areas so that they can be packaged into gastronomic tourism. The reason for choosing this topic is due to several reasons, firstly that culinary tourism activities are dominated by restaurants in urban areas.This condition leads to an educational process of the value of traditional foods in the form of the origin of the raw materials, the process, and the history of the food are not well socialized. In order to have a good integration between natural tourist attractions and local culinary attractions, the concept of gastronomic tourism is considered appropriate to be brought to rural areas. Where the form of tourism can be packaged by utilizing the activities of the village community which are still original to collect raw materials to show the traditional processing methods of the food and drink. The second reason for choosing this topic is, from the literature search, it was found that there was still a lack of research that specifically raised the concept of gastronomic tourism, especially focusing on the Tomini Bay area of Gorontalo Province.Olele Village.Olele Village is located in Kabila District, Bone Bolango Regency, which is on the southern coast of Tomini Bay. Olele Village can be reached +60 minutes distance from 
Gorontalo City Center by two-wheeled or four-wheeled vehicles. The main attraction that has been developed in this village is underwater tourism of coral reefs. Since 2006, through a Decree of the Regent of Bone Bolango Regency, the waters of Olele Sea have been designated as a Marine Conservation Area, so the main activities carried out by domestic and foreign tourists who come to Olele are snorkeling and diving. The economy of Olele Village is generally dominated by the fisheries sector, where most of the people work as fishermen. The questions to be answered in this research are (1) what are the potentials of traditional food in Olele Village, Tomini Bay Area, Kab. Bone Bolango which can be packaged as a Gastronomic Tourism Attraction?; (2) What is the appropriate gastronomic tourism development model in Olele Village, Tomini Bay Area, Kab. Bone Bolango?

\section{METHOD}

This research use desciptive qualitative approach. This research took place in Olele Village, Bone Bolango Regency, the coast of Tomini Bay by considering the potential natural attractions and the richness of marine resources. Various potentials of traditional food are identified and then analyzed using indicators of the concept of gastronomic tourism, which as an alternative to work, increase the income of local residents that can promise long-term welfare. Primary data collection was carried out by observation at the research location and in-depth interviews with selected informants using purposive sampling technique. Some of the informants included, the Village Government, the Tourism Awareness Group (Pokdarwis), MSMEs local culinary businesses, PKK women's group who are often involved in village cuisine competitions. Secondary data were collected through searching information from the Internet, related agencies, online journals and books.

Data analysis in qualitative research is an ongoing process, starting from interpreting data, deepening understanding, reflecting on data, developing analytical questions, and making notes throughout the study ${ }^{[5]}$. According to Miles \& Huberman ${ }^{[6]}$ In data analysis in qualitative research, there are three stages of activities that can occur together consisting of data reduction, data presentation, and drawing conclusions or verification.

\section{RESEARCH RESULTS AND DISCUSSION}

Identification of Traditional Seafood Made from Raw Food in Olele Village: Olele Village is located in Kabila District, Bone Bolango Regency, which is on the southern coast of Tomini Bay. Olele Village can be reached +60 minutes distance from Gorontalo City Center by two-wheeled or four-wheeled vehicles. The main attraction that has been developed in this village is underwater tourism of coral reefs. Since 2006, through a Decree of the Regent of Bone Bolango Regency, the waters of Olele sea have been designated as a Marine Conservation Area, so the main activities carried out by domestic and foreign tourists who come to Olele are snorkeling and diving. The economy of Olele Village is generally dominated by the fisheries sector, where most of the people work as fishermen. The fishing gear used by the fishing community in Olele Village is still traditional, between hand lines, gill net, fishing line, and fish sarong, especially tuna, which are used to accelerate the movement of the fish to the surface. The way the tuna glove works is to hold the fin of the fish that carries out the swimming force to the sea surface.

Based on observations in the field, the type of local food that is the mainstay of Olele Village, is food made from raw tuna fish. This is supported by the condition of natural resources that place Tuna as the highest fishery commodity in Olele Village, followed by other marine products such as squid, oci, etc. Although processed foods made from tuna are almost available in all areas of Gorontalo and Sulawesi, tuna culinary in Olele Village has its own advantages, including (1) Fresh fish catches that 
can be obtained only by going to sea +1 hour from the coast of Olele; (2) Having export fish meat quality; (3) Can be enjoyed directly by processing traditional Gorontalo-style dishes on the coast of Olele.

In Nugraha and Suharso's research ${ }^{[7]}$, the types of tuna found in the waters of Tomini Bay, including those obtained in Olele Village, are yellowfin tuna (Thunnus Albacares). This fish is one of the largest types of tuna, although it is still less big when compared to bluefin tuna and big eye tuna. This fish has high economic value and has a large body with a length from the tip of the snout to the fork of the tail fin reaching $195 \mathrm{~cm}$, but generally up to $150 \mathrm{~cm}$. This type of fish can dive deep into the sea. Yellowfin tuna have a habit of swimming fast and in groups with fish of the same size, sometimes mixed with other types of tuna. Excellent nutritional value of tuna, Its omega-3 content makes tuna have a thousand and one health benefits for the body. However, this must be supported by good tuna selection, processing and storage. Tuna that is still fresh should be stored in the refrigerator (if it is going to be used immediately) or frozen (if you want to keep it for a while). The iodine content in tuna fish reaches 28 times the iodine content in freshwater fish. Iodine plays an important role in preventing goiter and increasing children's intelligence. In addition, tuna is also rich in selenium. Consumption of 100 grams of tuna is enough to meet 52.9 percent of the body's need for selenium. Selenium has an important role in the body, namely activating the antioxidant enzyme glutathione peroxidase. This enzyme can protect the body from free radical attack that causes various types of cancer.

In a day, the fishermen in Olele Village can catch an average of three yellowfin tuna. Fishermen in Olele Village catch tuna using only katinting boats. Katinting is a small boat with two brothers or a traditional boat. Tuna that is caught by katinting boat weighs $63 \mathrm{~kg}, 40 \mathrm{~kg}$ and $29 \mathrm{~kg}$. In a day, fishermen get Rp. 5 million more, on average a day fishermen get one tuna, the selling price of tuna catches around 45,000/ kg. the catch varies depending on the weight of the fish caught. As for the capital once going to sea using a katinting boat, Rp. 50.00 to 100,000. This fee is to buy gas fuel or premium gasoline and other necessities while at sea. If gas is not available, gasoline will be used.

The catch of tuna fish in Olele Village is managed independently by the local community. Tuna that has been caught will be checked for quality first whether it meets the requirements for export or not. If it fulfills, the tuna will be cleaned first, the tuna will be cut off the head first, after separating it from the head, the tuna will be weighed and then the tuna fish will be cleaned in a way that the meat will be separated by filling it into 4 parts, put the tuna meat into the plastic that has been provided and put into a sterefoam box that is already filled with ice cubes, this is intended so that the fish is not easily damaged. Tuna only takes 1 hour from the fishing process to the ice storage process. The results of the tuna meat will be exported and sold.For the head, fish bones and tail are used as food ingredients which are sold to tourists and for the consumption of local people themselves. The head of tuna is a food ingredient that has high economic value and is a characteristic food for tourists in Olele Village. Food processing made from tuna fish which is usually served by the people of Olele Village as a gastronomic tour for both tourists who enjoy the beauty of Olele beach and tourists who do diving / snorkeling. The following is the process of processing tuna into a typical traditional dish by the Olele people with the highest demand by tourists:

1. Tuna Fish Satay: Sate or satai is food made from cut meat or fish smalland stabbed in such a way with a skewer of coconut leaf bones or seasonings then grilled using wood charcoal coals. Satay is served with a variety of spices depending on the variety of satay recipes. Sate is known to have originated from Java, in Indonesia satay can be found anywhere because it has been considered as one of Indonesia's national dishes. Sate tuna Gorontalo is a culinary specialty of Gorontalo which has a 
texture of fresh tuna meat, soft and savory taste, tuna satay can be served with peanut sauce or dabudabu chili sauce. The materials used to process Tuna Fish Satay are as shown in the following Figure 1 and 2.

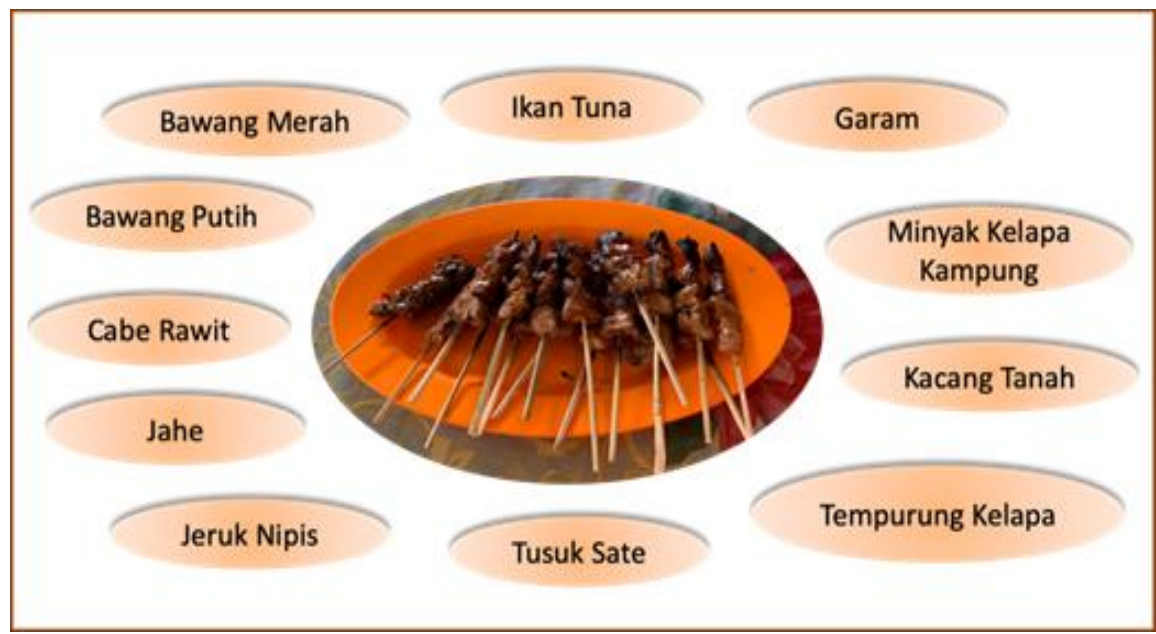

Figure1: Ingredients and Spices for Tuna Fish Satay ;( Source: Researcher Process, 2020)

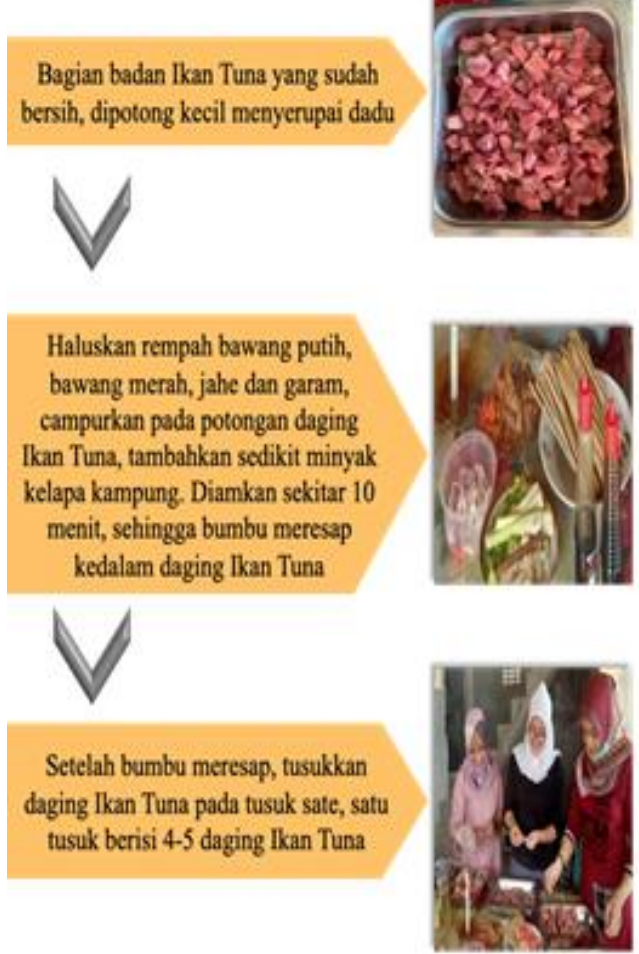

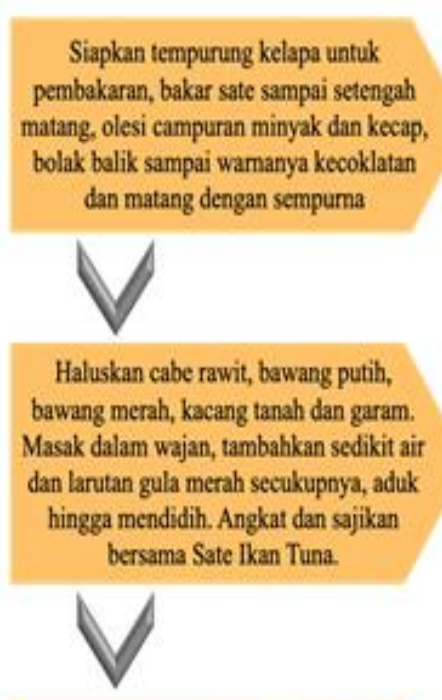

Haluskan cabe rawit, bawang merah, dan garam. Tambahkan sedikit air, dan minyak kelapa kampung. Tambahkan perasan jeruk nipis secukupnya. Aduk dan campurkan merata (tanpa dimasak), sajikan bersama Sate Ikan Tuna.
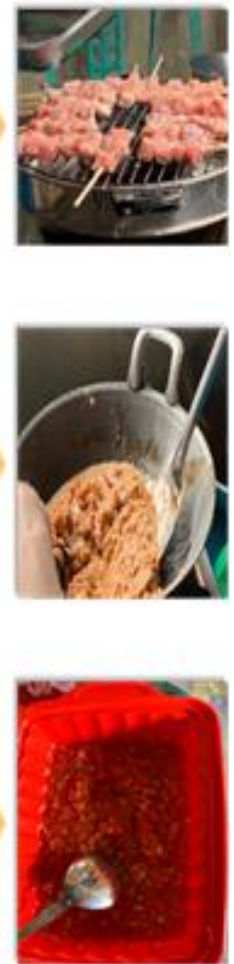

Figure 2: Stages of Tuna Fish Satay Processing Source: Researcher Process, 2020

2.Jaw \& Chest of Grilled Tuna:The jaw of the Tuna is the part of the head of the Tuna Fish that still has a lot of meat tucked between the bones. Unlike other types of fish, which only have bones in the jaw. The jaw is split and cut to a medium size. So that it is easy to burn and can be cooked perfectly. The Grilled Tuna Jaw is served with a typical Gorontalo spicy chili dabu-dabu chili. The materials used to process the Tuna Jaws are as shown in the Figure 3. 


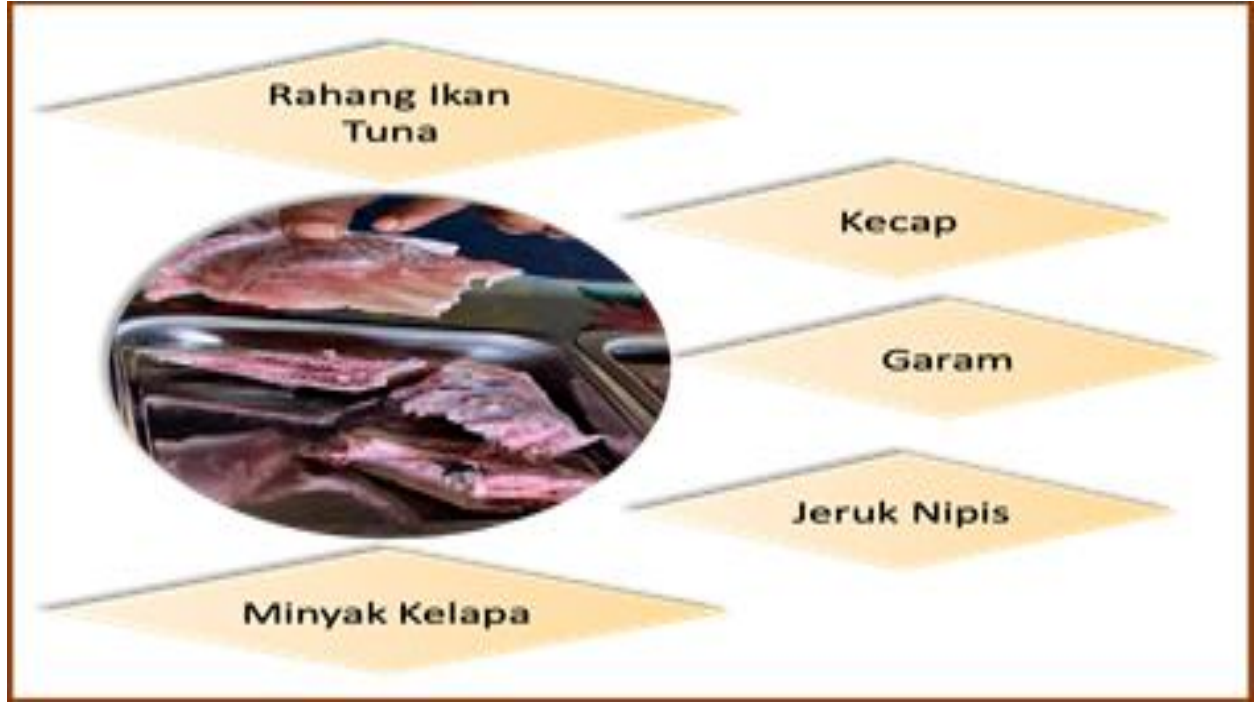

Figure 3: Ingredients and Spices for Grilled Tuna Jaws (Source: Researcher Process, 2020)

The processing stages for the Tuna Tuna Jaw are almost the same as the process of burning Tuna Fish Satay, it doesn't take a long time and is quite easy to do, as in the following Figure 4.

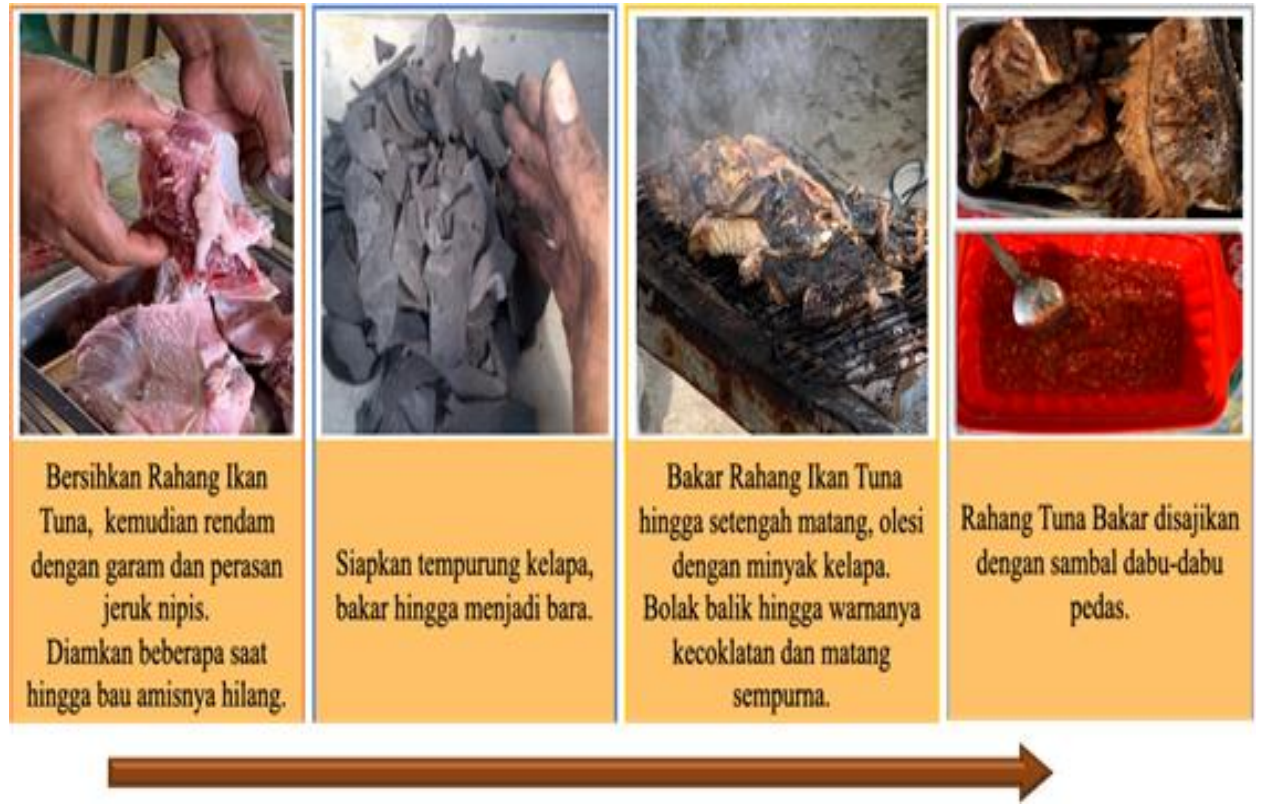

Figure 4: The stages of processing the jaws of roasted tuna Source: (Researcher Process, 2020)

3.Tuna Fish Sour Sauce:Processed Kuah Asam is a typical Gorontalo regional food which is usually called in the local language, Kuah Ilahe. The taste of the Tuna Fish Sour Sauce is very distinctive, contains a blend of sour, spicy and fresh flavors that can be an appetite generator. The ingredients used in making this menu process are as shown in the following Figure 5. 


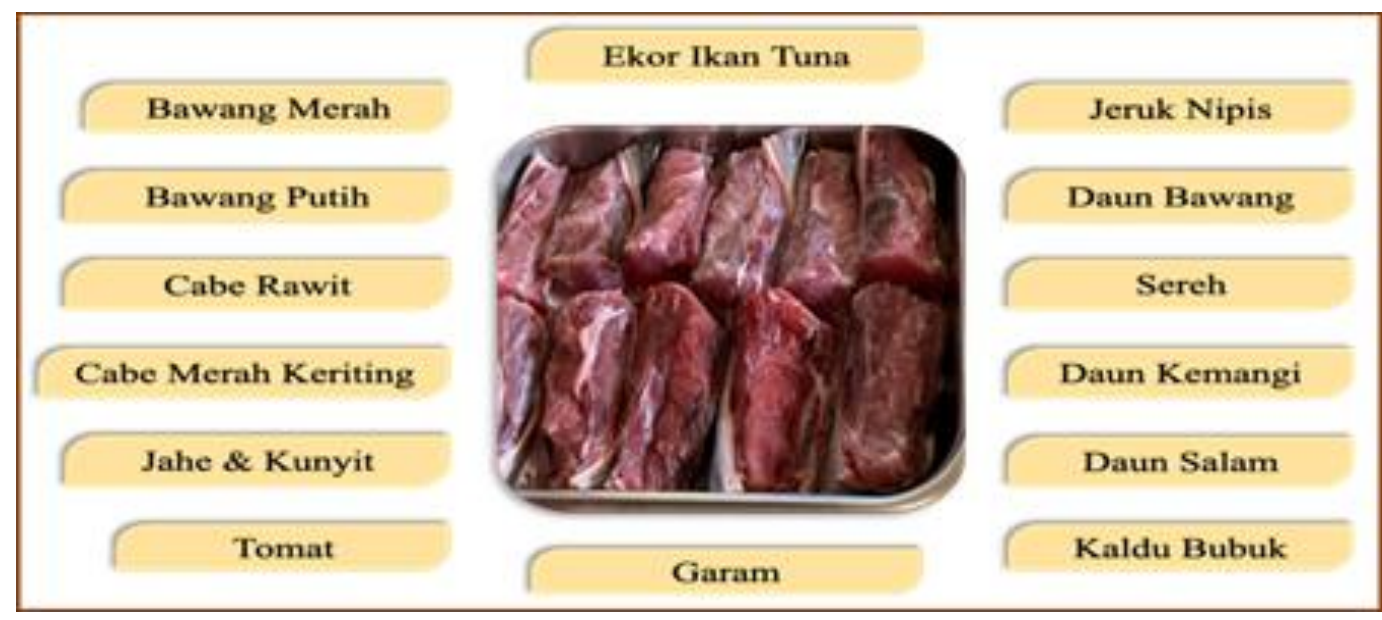

Figure 5: Ingredients and Spices for Tuna Fish Sauce (Source: Researcher's Documentation)

The process of processing the Tuna Fish Acid Soup menu is relatively easy, and it doesn't take too long. So that this food menu can be ordered at any time, as long as the fish and spices are available fresh. The spices and seasonings used are also very easy to find in traditional markets. Therefore, the people of Olele Village often make this menu for consumption as well as a superior menu which is often served to tourists who order food while they are in Olele Village. Here is how to prepare the spicy and fresh Tuna Fish Tuna Sauce menu in Olele Village.

Siapkan bagian ekor Ikan Tuna, bersihkan, diberi perasan jeruk nipis dan sedikit garam.

Didihkan air, masukkan Ikan Tuna. Jika sudah mendidih buang rebusan air pertama untuk menghilangkan bau amis dari ikan.

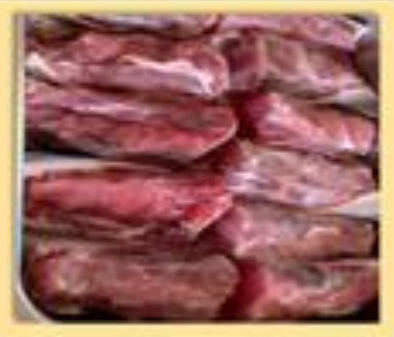

Tumis bumbu yang dihaluskan dengan sedikit minyak, tambahkan bumbu iris dan daun yang lainnya, masak hingga berbau harum.

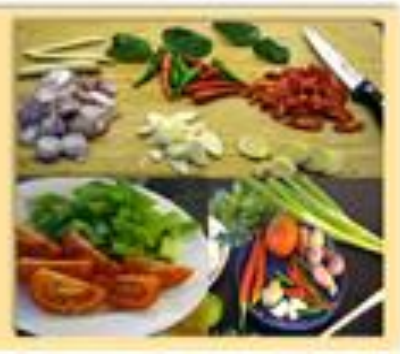

Figure 6: Stages of Tuna Fish Acid Sauce Processing （Source: Researcher Process, 2020)

\section{Penthe potential of Olele Village Traditional Food as an attraction Gastronomic Tourism:}

Based on the research results, Olele Village has the potential to develop their seafood into gastronomic tourism products. The elaboration of the potential along with the analysis of the needs for the development of this potential into a gatronomic tourist attraction are as follows:

1.Availability of physical facilities:The first step that must be done is planning of physical facilities to support gastronomic tourism activities that involve tourists in the food processing 
process. The physical facilities in question do not have to be required to be in the form of new buildings, but can optimize local residents' houses such as terrace areas. From the results of the researcher's observations, there are dozens of residents' houses that have the potential to be optimized as a gastronomic tourism center with the consideration of having a strategic location which is only $+15-20$ meters from the coast and very close to tuna processing centers. This of course must be supported by the application of the concept of food processing activities that are according to standards, starting from the availability of processed food recipes, cooking utensils, eating and drinking utensils,

\section{Implementation of Sanitation and Hygiene Standards for Physical Facilities and Food} Processing based on the Covid-19 "New Normal" protocol:Based on the results of field observations, all tourism activities in the Olele Village area have not at all shown the implementation of the "New Normal" tourism standard which has been socialized by the government. There is no provision of a hand washing area and temperature measurement in the gate area. Particularly for the development of gastronomic tourism, the thing that must be considered is the application of sanitation and hygiene standards for physical facilities and fish processing which must conform to the "New Normal" protocol of the Covid 19 pandemic era. This is done to ensure the trust of potential tourists before visiting a tourism destination and choosing to perform gastronomic tourism activities. Although this tourism activity is categorized as a tourism activity on the UMKM scale, the application of standard protocols in fish processing, cooking,

Local people must be given training on food processing standards as socialized by Directorate General of Strengthening the Competitiveness of Marine and Fishery Products (Ditjen PDSPKP), KKP at SNI 1: 2011 includes: monitoring source and origin of raw materials, application of physical distancing during the fish processing process, routine personal health checks every day, health inspections of anyone who will enter the fish processing area (washing hands, measuring temperature, and using masks), and providing sanitary tools to PPE clothes .

Apart from the fish processing side, the implementation of this protocol is also importants is applied to the culinary activity of serving food according to the concept of 6 (six) New Normal restaurant protocols issued by World Travel \& Tourism Council yaki; (1) prioritizing health and cleanliness of restaurant services; (2) Limitation of Social Distancing during eating and drinking activities; (3) Minimizing touch points, for example replacing printed food menu sheets with digital food menus that can be sent via online or bluetooth offline applications via Whatssapp, Messenger, etc. (4) Enables direct contactless payments such as digital transfer payments; (5) Wash hands when entering and leaving the dining area; (6) Restrictions on parking areas

\section{Increase the capacity of human resources of local communities as managers of gastronomic} tourism:Local Human Resources are the main key in developing gastronomic tourism. From the research results it was found that most of the local people's knowledge was limited to culinary tourism activities. They stated that there were several requests from some tourists to enjoy tuna culinary at people's homes after diving and snorkeling tourism activities, but these tourists were not involved in the processing of tuna into local cuisine. Therefore, community empowerment efforts are needed to master the skills as a food processor, food presenter, and being able to market these food products.

The government should be able to involve all stakeholders ranging from tourism academics, fisheries academics, restaurant business players, as well as media parties and even social media marketing influencers. The involvement and cooperation of stakeholders can be in the form of formulating community empowerment programs in processing and managing their food resources 
into a gastronomic tourism activity. Training programs that can be carried out include:

- Training on traditional food processing with local ingredients, arrangement and presentation;

- Sanitation and hygiene training for food, beverages, tools and equipment, as well as their environment;

- Restaurant business management training, including simple financial management (food cost, pricing), food and drink services for customers / tourists;

- Digital marketing training in order to promote gastronomic tourism in tourist areas;

- Socialization / workshop on the meaning of culinary tourism, gastronomic tourism and its relation to local culture.

These trainings should be carried out gradually and continuously and accompanied by mentoring and evaluation activities, so that local people who have understanding and mastering skills in gastronomic tourism can be realized. Through the diversification of the tourist attractions of Olele Village, which were limited to marine tourism activities (snorkeling and diving), combined with other attractions, namely Gatronomi Tourism, business opportunities to improve the welfare of rural communities will be more easily realized.

\section{CONCLUSION}

The traditional processed food menus offered by Olele Village, namely Sate Tuna, Jaw / Tuna Grilled Tuna, and Kuah Asam Tuna are original menus from the Gorontalo Region and are a recipe from generation to generation. The unique series of manufacturing / processing processes can be an attraction that combines culinary arts (food) and local culture in this village. Referring to these conditions, traditional food in this village can be picked up and packaged into a gastronomic tourist attraction to support its natural tourist attraction. The obstacles that Olele Village still face in preparing itself as a gastronomic tourist destination are First, the lack of availability of physical facilities that can accommodatefood processing activities according to standards and have appropriate tables and chairs according to the capacity of the room provided. Second, the lackHuman resources who have the ability to package tourism activities ranging from processing raw materials, cooking processes, to serving as well as providing some kind of assistance as local guides in explaining the food processing process from start to finish.

\section{SUGGESTION}

The development of gastronomic tourism will be optimal if the involvement and cooperation of stakeholders can be well established and in accordance with their respective fields. There needs to be a good planning and arrangement of the concept of gastronomic tourism, both in terms of physical facilities (Tangible) in accordance with sanitation and hygiene standards (using the New Normal tourism protocol), as well as non-physical such as increasing human resource capacity (intangible). The seriousness and consistency of local communities in terms of participating in preserving local culture which is represented through traditional regional food must also be developed. So that local people do not only act as providers of traditional food products, but further promote the traditional food using the right strategy.

\section{ACKNOWLEDGEMENT}


Gratitude to the LPPM Gorontalo State University for financing the implementation of this SocioCultural research scheme, all informants of the Olele Village community, and related agencies, namely the District Tourism Office. Bone Bolango and the Gorontalo Province Marine Fisheries Service have provided the information that the author needed.

\section{REFERENCES}

1. R.Tridayanti \& D.Turgarini, Angleng as Gastronomic Heritage and Destination Attraction in Kampong Nihmat, Cigugur Village, Parongpong District, West Bandung Regency. 3rd International Seminar on Tourism (ISOT 2018),2019, (pp. 78 - 81). Atlantis Press.

2. A.Sahabudin, R. Dienaputra \& A.Nugraha, Development of Potential Gastronomic Tourism Attractions in Desa Cililin Kab. West Bandung. JUMPA,2019, 87-95

3. D.Turgarini \& R.S.H.Pridia, Gastronomy Tourism Attraction in Ternate City. 1st International Conference on Tourism Gastronomy and Tourist Destination (ICTGTD 2016) (pp. 90-96). Atlantis Press.2016.

4. Clave and Knafou, Gastronomy tourism and globalization. Paris: Universitat Rovira i Virgili - Tarragona, Université Paris 1, 2012.

5. Cresswell, Research design: qualitative, quantitative, and approaches mixed. Yogjakarta: PT Pustaka Pelajar, 2010.

6. Miles \& Huberman, Book Qualitative Data Analysis Resources About New Methods. Jakarta: UIP, 1992.

7. Nugraha, Budi; Suwarso, Yellowfin Tuna (Thunnus Albacares) fishery in Marisa waters, Tomini Bay. Bawal Widya Capture Fisheries Research, 2006, 107-111.

\section{Author Profile}

Yumanraya Noho, S.Pd., M.Sc. is a Lecturer in the Department of Tourism, Faculty of Letters and Culture, Gorontalo State University (UNG). Completed S1 English Education at Gorontalo State University in 2010, and Masters in Tourism Studies from Gadjah Mada University (UGM) in 2014. Currently, he serves as Chair of the Gorontalo State University Tourism Study Program. Some of the subjects taught are ecotourism, tourism marketing, and tourism geography.

Meilinda Lestari Modjo, MM.Par. is a lecturer is a Lecturer in the Department of Tourism, Faculty of Letters and Culture, Gorontalo State University (UNG). Completed Diploma studies IV Tourism Management (MKP) at the Bandung Tourism College (STPB) in 2000, and Masters in Tourism Administration at the Bandung Tourism College (STPB) in 2010. Currently, he is active in tourism organizations such as the Association of Hotels of the Republic of Indonesia (PHRI) Gorontalo Province and Regional Tourism Promotion (BPPD) Gorontalo Province.

Poppy Arnold Kadir, MM.Par. is a lecturer is a Lecturer in the Department of Tourism, Faculty of Letters and Culture, Gorontalo State University (UNG). Complete undergraduate studies Hospitality Management at the Semarang Tourism Economics College in 2001, and Masters Hospitality Management at the Bandung Tourism College (STPB) in 2013. Currently 
active in tourism organizations, namely the Association of Hotels of the Republic of Indonesia (PHRI), Gorontalo Province.

\section{*Corresponding Author: Yumanraya Noho,}

Department of Tourism, Gorontalo State University, Gorontalo, Indonesia yumanraya@ung.ac.id

Online publication Date: 10.11.2020 